\title{
Светителот - скротител на дивите sверови. По примерот на св. вмч. Мина Чудотворец
}

Abstract: Lucheska Eli, Svetitelot - skrotitel na divite dzverovi. Po primerot na sv. vmch. Mina Chudotvorec (Saint - The Tamer of the Wild Beasts. By the Example of the St. Martyr Mina the Miracle-Maker). "Poznańskie Studia Slawistyczne" 20. Poznań 2021. Publishing House of the Poznan Society for the Advancement of the Arts and Sciences, Adam Mickiewicz University, pp. 273-298. ISSN 2084-3011.

The basic and main topic of this research paper is the cult of St. Martyr Mina, especially his ability to tame the wild beasts-the wolves. The starting point of this paper is publication, written by V. Popovska Korobar about the wall paintings from the XV century in the monastery church St. Petka in the village of Brajchino, region of Prespa in Macedonia. In this church the saint is portrayed with some fairly rare iconographic elements that out framed the usual monumental painting of that time - the saint is portrayed as a victorious handler of tamed wild beasts. Popovska Korobar supposes that this kind of interpretation is related with the saint's life in the desert together with the wild animals, or with the description of the beast in the existing literature about her life in Egypt - the monster with a camel's head, and she does not identify the species of the animals depicted on the wall of the church. According to our research, this type of iconography is created and based upon the hagiographic texts in combination with the folklore identity of St. Mina and according to that, we think that the wild beasts are tamed wolves.

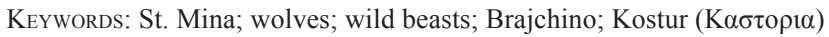

Историчарите на уметноста се занимаваат со датирањето на стилско-ликовните карактеристики на фрескоживописот и иконописот, оставајќи го настрана интересот не само за нивното поклонение кое го вадат од т.н. црковно-богослужбен и литургиски концепт, туку и нивната почит која ја сметаат за маргинална појава и ја припишуваат на т.н. „народна религиозност“, односно на религијата на широките народни маси. Меѓутоа, во одредени случаи, како што е примерот со ретката ликовна претстава на св. вмч. Мина - скротител на 
дивите sверови во манастирската црква Св. Петка (Брајчино, Преспа), точно, народниот култ кон светителот ги „декодира“ иконографските елементи кои историчарите на уметноста со нивната методологија на истражување не можат да ги протолкуваат. Од друга страна, ни Светата црква, како во средновековието, така и денес не е „имуна“ од влијанието на народната религиозност, а особено при составувањето на хагиографиите на светителите. Всушност, „хагиографската ускладеност“ (les coordonnees hagiographiques) - термин воведен од болондистот Иполит Делееј (Нyppolyte Delehaye), е востановена како еден од најзначајните принципи во поглед на придавањето на подеднаква важност, како на литературните, така и на нелитературните сведоштва и очигледните неисториски, легендарни, усни извори кои заслужуваат да бидат земени во предвид при составувањето на житијата на светиите (Delehaye, 1961; Омеслеге, 2008, 216-221). Генезата на легендарните извори, пак, потекнува од сферата на фолклорот, исто како и многубројните преданија кои се однесуваат на чудата кои ги направил одреден светител (Gurevič, 1987, 76-101; Луческа, 2018, 46-53; Баева, 2013). Притоа, во сите развојни етапи и форми од почитувањето на светителите, посебно место зазема токму чудото, како заеднички именител, околу кој настанува „внатрешната акултурација“, односно доaѓa до внатрешното прилагодување помеѓу официјалното и народното христијанство1. Во ликот на светителот (дво)единството на светоста и чудотворството имаат најголема вредност во очите на верниците. Со овие „знаци“ се исполнети хагиографските и химнографските текстови, народните преданија, легенди и раскази поврзани со мачениците и светителите. Преку овие знаци, светителите се јавуваат како „претставници на сила, повисока од таа на традиционалните верувања, а не како носители на радикално различно чувствување на светоста или тип на религиозност“ (Kaplan, 1984, 115). Притоа, поседувајќи

${ }^{1}$ Без посебно да навлегуваме во оваа проблематика, ќе забележиме дека истражувачите се, главно, согласни околу тврдењето дека „народното влијание го одредил односот на свештенството спрема чудата“", зашто колку и да се трудело свештенството да им објаснува на верниците дека во светителот е најважно „неговото одвојување од сѐ што е световно, комуникацијата со вишите сили, аскетскиот подвиг, моралното совршенство и чистотата, «подражавањето на Христос», сепак тие барале чуда“" (Gurevič, 1987, 72, 79). 
такви способности, тие се „специјализираат“ да бидат покровители на различни сфери од човековото живеење, односно се носители на одреден тип на функции, како на пример, функција на посредници, на заштитници, на исцелители, етичко-нормативна функција, плодоносна функција и сл. (Луческа, 2010а, 91-92). Функционалните и типолошките карактеристики на светителите во голема мера се условени како од нивните хагиографии, така и од нивното место во годишниот календарски систем каде доаѓa до меѓусебно испреплетување на канонскиот култ кон светителот со обредноста на традиционалниот празничен календар. Ваквиот пристап на истражување претставува релативно нов научен проблем на полето на проучувањето на ликовите на светителите од областа на хуманистичките и општествените науки (Стоилов, 1997; Луческа, 2010а; Стоилов, 2017). Истиот ќе се обидеме да го примениме преку разоткривањето на „моделот“ на градење и негување на култот на веќе спомнатиот великомаченик св. Мина во македонската ликовна уметност и народна традиција, при што посебен акцент ќ биде ставен на неговата способност за скротување на дивите sверови - волците. При докажување на тезата ќе го користиме компаративниот метод кој е најчесто употребуван научен инструмент во барањето на потеклото на културните појави, односно генетската врска помеѓу иконографската претстава и преосмислената канонска почит на св. вмч. Мина во народното сознание како заштитник од дивите sверови - волците, во нашиов конкретен случај. Тоа подразбира дека ќе биде нагласена интеракцијата помеѓу изворите од историјата на христијанската уметност, хагиографските текстови, средновековната книжевност и етнологијата, односно фолклористиката. Меѓузависноста на овие дисциплини нѐ упатува на примената на интердисциплинарниот метод кој се јавува како нужна претпоставка за успешно научно истражување и толкување, односно ликовните и книжевните референци на продуктивен начин се поврзуваат со емпирискиот материјал од областа на народната религија и етнографската документарна граѓа од теренските истражувања.

Во оваа насока темата за светителите - скротители на дивите sвeрови речиси и да не била предмет на сериозно научно проучување и истражување како дел од богатата духовна традиција и културна историја на Македонија. Единствено постојат три научни труда за 
скротување на мечки, од кои два се однесуваат на св. Наум (Матичетов, 1975, 129-145; Моллов, 2000), а еден на св. Гаврил Лесновски (Моллов, 2001). Темата која е предмет на елаборирање на нашиот труд досега не била предмет на истражување не само во Македонија, туку и пошироко кај останатите словенски земји, со исклучок на трудот на Рачко Попов $(2004,79-88)$ каде низ етнолошка анализа се претставени народните верувања и претстави за св. Мина кај балканските народи.

Кој е св. великомаченик Мина Чудотворец? За личноста, животот и смртта на овој светител постојат голем број на извори напишани на коптски, грчки, старонубијски, етиопски, латински и арапски јазик (Zekry, 2017, 38). Сепак, според истражувањата на Џејмс Дрешер (James Drescher), за историската личност на св. вмч. Мина се знае многу малку, а раните извештаи за неговиот живот се доста апокрифни, легендарни и контрадикторни по својот каратер (Drescher, 1946, i-x). Постојат два главни, официјални литературни извори, коптскиот Мартирдом (Coptic Martydrom) и Енкомиумот (Coptic Encomium), кои се препишани и преведени во IX или $\mathrm{X}$ век, а кои произлегуваат од грчкиот Мартидром (Greek Martydrom) (Drescher, 1946, xxxiii-xxxvi; Malek, 1981, 99; Piwowarczyk, 2018, 361-375). Според нив, доколку се претпостави дека св. Мина навистина постоел, има три можности: 1) Св. Мина бил Египќанец кој живеел и умрел во Египет (Delehaye, 1922, 31); 2) Св. Мина бил фригијски мартир и 3) постоеле двајца светители со истото име, едниот Египќанец, а другиот Фригиец и биле измешани од хагиографите (Drescher, 1946, ix-х). Постои и четврта хипотеза според која св. Мина не е историска личност туку е заменет со некое паганско божество (Хорус, Мин и сл.) (Ramsay, 1918, 166).

Според наведените извори, св. вмч. Мина² бил роден Египќанец од Никуа (Nikiou), кој служел како војник во Котуанската област во Фригија, Мала Азија за време на владеењето на римскиот император Диоклецијан. Како христијанин, не можејќи да ги гледа паганските жртвопринесувања, ги напуштил градот и војската и отишол да живее во пустината, бидејќи повеќе сакал да „живее со дивите sверови

\footnotetext{
${ }^{2}$ Хагиографската литература разликува два маченици со името св. Мина, едниот е војник со египетско потекло на служба во Фригија каде што и пострадал (11.XI) (кој е предмет на нашиот интерес), а другиот е ретор, родум од Атина, кој пострадал во Александрија (10.XII) (Житија светих, 1961, 899-900, 986).
} 
отколку со луѓето кои не знаат за Бог“. Кога по наредба на императорот одбил да се поклони на паганските идоли, бил жестоко измачуван и на крајот обезглавен на 15 Хатур (15 Hatur) 296 г. (Krause, 1991, 1589-1590).

Во однос на посмртните остатоци од маченичкото тело и во грчките и во коптските хагиографски извори се известува дека тие биле пренесени од Котуан во Египет. Разликата во овие извори се однесува на начинот на нивниот пренос. Според грчките извори моштите на св. вмч. Мина биле пренесени од неговото семејство, а според коптските извори, светите мошти биле земени како реликвии од страна на командантот на војската, кој и самиот бил христијанин. Легендата понатаму не́ известува дека додека војската патувала по море кон Египет била нападната од некакви животни со долги вратови и лица слични на главите на камили, но истите биле избркани од пламенот кој излегол од посмртното тело на маченикот. Темата со камилата се повторува уште еднаш кога телото на светителот било ставено на грбот од камила во близина на Езерото Мариот (Mareotis), на 45 км југозападно од градот Александрија. Имено, камилата одбила да стане, а истото се случувало и со другите камили, па настанот бил интерпетиран како желба на великомаченикот дека на тоа место сака да почиваат неговите свети останки, и тука бил и закопан (Drescher, 1946, 61142). Гробот на св. вмч. Мина останал непознат подолго време се́ додека не започнале да се случуваат многубројни чуда ${ }^{3}$.

Всушност, почетокот на култот кон св. вмч. Мина, според Енкомиумот, е поврзан со чудотворното исцеление на некое момче, кое било инвалид од неговото раѓање и кое оздравело откако преспало

${ }^{3}$ Tоа било причина, во доцната антика, кон крајот на IV век, над неговиот гроб да се подигне мал ораториум со тетрастолбови, по што започнале да се градат голем број на цркви околу светото почивалиште на маченикот. Набрзо бил изграден и град Абу Мина (Abu Mina), наречен по светителот, кој станал голем поклонички центар, откриен со археолошките истражувања во 1905 г. од Карл М. Кауфман (Kaufmann, 1910; Krumbacher, 1907, 31-43; Grossman, 1981, 125-176).

Подетално за чудата на св. вмч. Мина v. J. Sanidopoulos (2009), The Great Egyptian and Coptic Martyr (2005, 21-23, 48-62), Redigolo (2011/2012, 11-23 со цитираната литература). Исто така, голем број на чуда се забележани дигитално и на веб-страната од манастирот посветен на св. Мина, во близина на Александрија: http://www.stminamonastery.org/miracles.htm. 
на гробот на маченикот. Според Синаксарот (Synaxarion), пак, некој овчар ги пасел своите овци во близина на гробот на маченикот. Една од овците, која била шугава, влегла во водата од цистерната која се наоѓала во близина на гробот, а потоа се стркалала на земјата и чудесно се исцелила. Вчудоневидениот овчар сите заболени овци ги внесол во водата, а потоа ги тркалал во земјата покрај гробот на светителот и тие, сите до една, чудотворно биле излечени (The Great Egyptian and Coptic Martyr, 2005, 21-22).

Култот кон св. вмч. Мина толку многу се раширил, што поклоници од речиси целиот христијански свет започнале да го посетуваат градот Абу Мина, здобивајќи се со исцеление преку посредништвото на светителот, кој станал познат како Чудотворец ${ }^{4}$. Во прилог на тоа говори и фактот што неговото светилиште како едно од најславните поклонички места било посетувано дури и после арапските освојувања во VII век, кога истото било уништено и напуштено (Maraval, $1985,322)^{5}$.

Во византиската престолнина, два века подоцна, дошло до појава на нов светител со истото име, а по чудесното пронајдување на светителските мошти, опишани во некои синаксари. Легендата раскажува дека за време на владеењето на цар Василиј I (867-886), св. вмч. Мина му се јавил на сон на некој војник и кажувајќи му го неговото име:

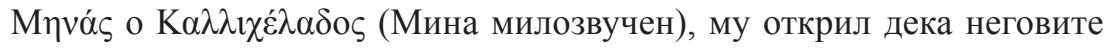
мошти се наоѓаат покрај Акрополисот 6 . На тој начин типикот на Великата Црква, како и менологот на Василиј II веќе разликувале двајца

\footnotetext{
${ }^{4}$ Доказ за тоа се бројните керамички ампули и шишиња за света вода или масло на кои се испечатени името и ликот на св. вмч. Мина, а кои археолозите ги наоѓаат во различни земји ширум Средоземниот свет, како што се Милано во Италија, Далмација во Хрватска, Марсеј во Франција, Донгола во Судан, Меолс (Cheshire) во Англија, Хајделберг во Германија, и во светиот град Ерусалим, како и во модерна Турција и Еритреја (http://www.stmina-monastery.org/ampullae.htm; за нивните форми и иконографија v. Cabała, 1969, 107-118 и Kiss, 2015, 231-248).

5 За големата почит која ја имал св. Мина во доцната антика говори и изградената црква со негова дедикација во Цариград уште во V век од страна на царицата Пулхерија и царот Маркијан (450-457) (Janin, 1934, 340-342).

${ }^{6}$ Откако на посоченото место бил откопан сандак со мошти на кој пишувало дека тука почиваат веќе 400 години, веднаш бил напишан хагиографски текст со страдањата на св. Мина „Каликелада“, придружен со уште двајца светители - св. Ермоген и св. Евграф (Марковић, 1995, 612-613).
} 
свети Мина, едниот се празнувал на 11 ноември (заедно со св. Виктор и св. Викентија), а другиот на 10 декември (заедно со св. Ермоген и св. Евграф) (Марковић, 1995, 612-613).

Според истражувањата на историчарите на уметноста промената која се случила со култот кон св. вмч. Мина предизвикала и промени во иконографијата на светителот. На најстарите претстави, помеѓу IV и VIII век има физиономија на млад човек, без брада и со кадрава коса, во позиција на орант, кој носи римска легионарска облека - туника и кламидија прикачена над едното рамо или вратот, опкружен со две камили од двете страни на нозете кои ги наклонуваат вратовите кон земјата (Woodfin, 2006, 114; Kiss, 2015, 231-248; Zekry, 2017, 39-43) 7 .

По иконоклазмот и појавата на св. Мина Каликелада иконографскиот тип на св. вмч. Мина (Египетски/Фригиски) претрпува промени. Почнувајќи од IX век неговата физиономија се променува од млад христијански војник во зрел византиски дворјанин со седа, густа, кадрава коса и брада, облечен во богата благородничка облека и се исликува во групата на светите воини. Освен тоа, доаѓа до целосно исчезнување на клучниот елемент од претходниот иконографски тип камилите (Woodfin, 2006, 117-118) ${ }^{8}$.

Во поствизантиската уметност се продолжило со исликувањето на востановената физиономија на египетскиот (фригискиот) маченик св. вмч. Мина како војник. Во оваа насока, ретки иконографски елементи кои отстапуваат од неговиот вообичаен приказ во монументалното сликарство се забележани од страна на Викторија Поповска-Коробар (2007, 549-551) во манастирската црква Света Петка кај Брајчино, која е изградена и фрескоживописана кон крајот на XV век (помеѓу 1486 и 1493 г.). Во програмата на фасадата, на северната и јужната страна, идејно се вклопени претставите на светите воини, Чудото на

\footnotetext{
${ }^{7}$ Оваа иконографија се повторува на илјадници репрезентации, вклучително и на поклоничките ампули, слоновата коска и камените релјефи.

${ }^{8}$ М. Марковиќ е на мислење дека најстарата сочувана војничка претстава на светителот со ваква физиономија во Македонија се наоѓа во црквата Св. Ѓорѓи, Старо Нагоричино, исликана во 1317 година. Според истиот автор, овој иконографски тип дошол преку Солун, градот од кој пристигнале зографите на црквата (Михајло и Евстатиј) (Марковић, 1995, 615), каде култот на св. Мина бил доста силен за што, меѓу другото, сведочи и големата базилика посветена на светителот која за прв пат се спомнува во 831 година (Janin, 1975, 397; Mantopoulou-Panagiotopoulou, 1996, 259-260).
} 
св. Ѓорѓи, кој убивајќи го змејот ја спасува принцезата и св. Мина на коњ, насликан како „војник со кожен панцир, со штит и копје под чиј врв се виори бело знаменце, со десната рака води три бели зверови со отворени челусти, а во позадината со ниската вегетација се кријат уште две такви суштества со лик на бесен пес“" (фот. 1 и 2). Притоа, забележува дека не се познати вакви примери на прикажување на св. Мина во монументалното сликарство, освен на иконатата на св. Мина, која денес се наоѓa на иконостасот на црквата Богородица архонта Апостолија (1605) во Костур 9 (Поповска-Коробар, 2007, 556-557).

На костурската икона св. вмч. Мина е прикажан како возрасен маж со седа, кадрава коса и брада. Облечен е во војничка опрема со панцир и црвена наметка, од оружје носи штит, меч и тоболец со лак и стрели, а преку рамото има копје со бело знаме на кое е прикажан црн крст. Светителот јава на коњ во галоп, а меѓу стилизираните возвишенија се прикажани три sверови со отворени челусти и подигнати уши. Два од нив се врзани со јаже кое е прикачено за седлото од коњот, а од едниот се гледа само главата која ја подава од карпестиот рид ${ }^{10}$. Поповска-Коробар $(2007,557)$, врз основа на стилските карактеристики, претпоставува дека иконата е од последната четвртина на XV век и е дело на непознат мајстор кој е поврзан со групата на зографите кои ја исликале црквата Св. Петка во Брајчино (фот. 3).

Во однос на скротените зверови, како на фрескоживописот, така и на иконата, авторката констатира дека тие не претставуваат визуелизација на ниедно чудо на св. Мина. Таа не ја исклучува можноста дека истите се сликарската интерпретација на животот на светителот „во пустината со дивите животни, или литерарниот опис на чудовиштето со глава на камила од египетската верзија на житието“ и дека сцените се соодветен пример за „истражување на ликовите на светителските средби со животните“. Притоа додава дека „да се избере живот помеѓу дивите животни и да се живее во мир со нив, е дел од безгрешниот и чист живот, каков што е монашкиот“" (Поповска-Коробар, 2007, 557).

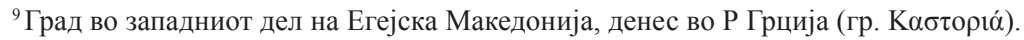

${ }^{10}$ Описот на иконата го направи колегата м-р А. Василески, на што му заблагода-
} рувам. 


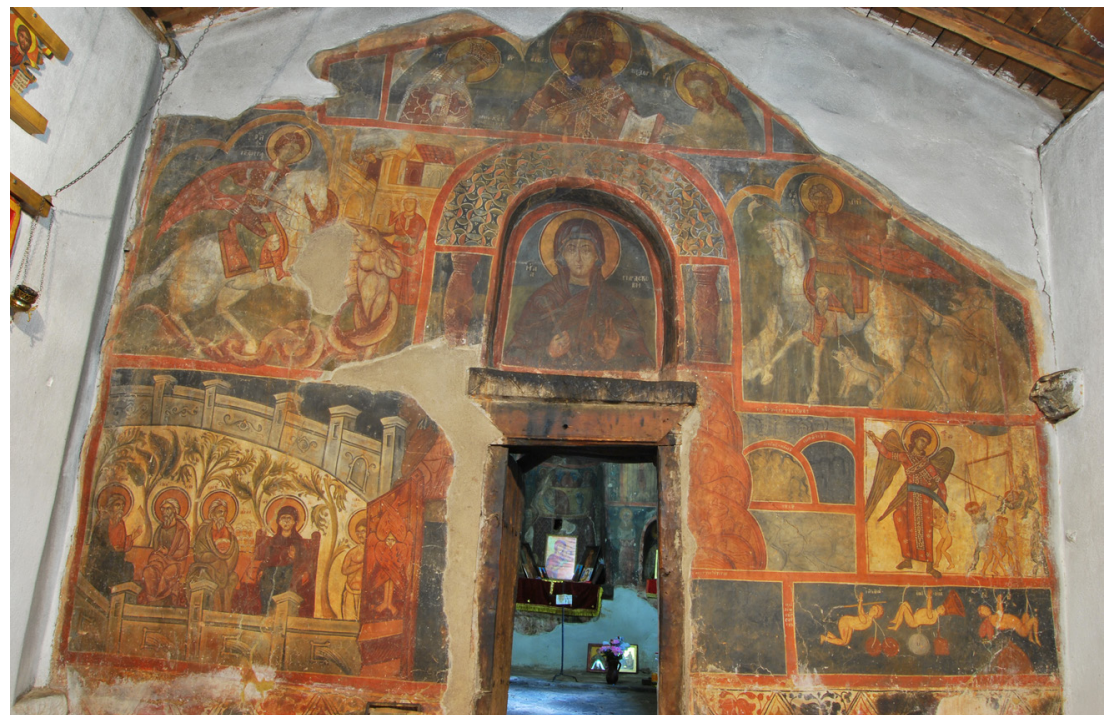

Фот. 1. Западна фасада на црквата Св. Петка, Брајчино



Фот. 2. Св. Мина со скротените волци, Св. Петка, Брајчино 


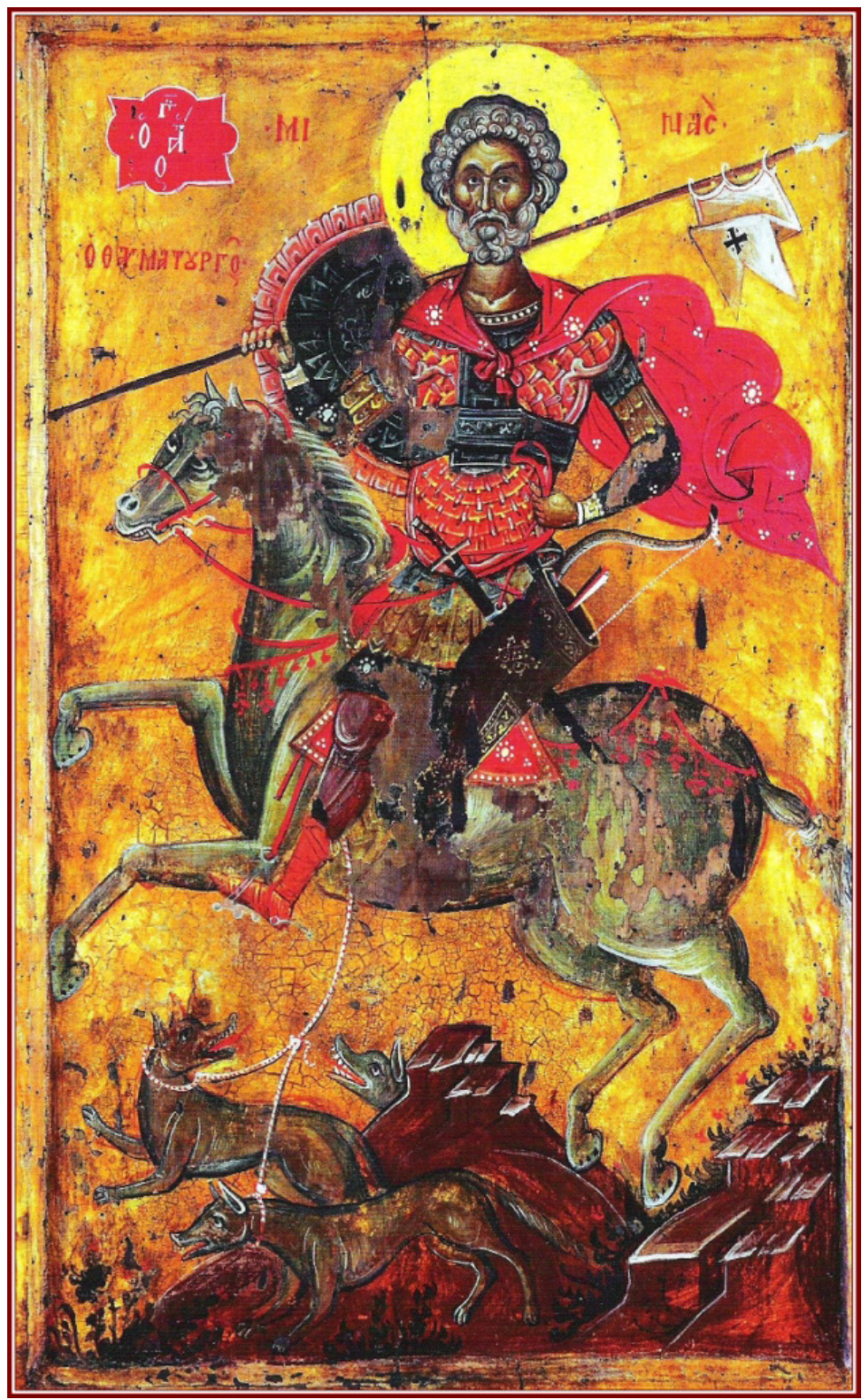

Фот. 3. Св. Мина со скротените волци, Костур, последна четвртина на XV в. 
Несомнено, топосот на светителски средби со животните (sверовите) зазема посебно место во средновековната хагиографија. Неговите зачетоци би требало да се побараат во IV и V век во тесна врска со херојските, аскетски подвизи на светителите-анахорети во египетската пустина (Dominic, 2008, Chapter 2), кои биле во постојани контакти со дивите sверови, а честопати и придружувани од нив. Религискиот контекст на оваа релација потекнува како од класичната традиција, така и од библиските извори. Во првата библиска книга, Битие (Прва книга Мојсеева), читаме како Бог ги создал sверовите: „И Бог создаде зверови земни, според родот нивни“ (Свето писмо, 2017, 1. Мојс., 1:25); како му дал доминација на човекот над животните: „овладајте ги морските риби (и sверовите), [...], и сите животни што лазат по земјата!“ (Свето писмо, 2017, 1. Мојс., 1:28) и како ги довел животните пред човекот за да ги именува: „И им даде човекот имиња на сиот добиток, [...] и на сите полски sверови“ (Свето писмо, 2017, 1. Мојс., 2:19, 20).

Меѓутоа, првопочетниот грев посеал непријателство помеѓу човекот и Бога, и помеѓу човекот и видливата природа. Притоа колку повеќе човекот се борел против гревот и му се враќал на Бога, дотолку и природата повторно му се потчинувала како на свој господар. Примерите на светителите, првостепено на пустиножителите-анахорети, ова сликовито го потврдуваат во нивните хагиографии каде, со ретки исклучоци, дивите зверови, речиси секогаш, им се „скротуваат“, „умилкуваат“, „не им наштетуваат“, „не ги допираат“ и сл. ${ }^{11}$ Ваквата теолошка рамка во хагиографските текстови има за цел повторно да го пресоздаде времето на Еденскиот рај, кога човекот, пред сторениот грев, имал власт над животните. Оттука, односот на светителот со животинскиот свет е честопати знак за светоста на светиот човек, која

\footnotetext{
${ }^{11}$ Неколку примери: преп. Теодосиј Велики (11/24.I) „И Бог го обдари со дарот на чудотворстовото, па [...] sверови скротуваше“; св. мч-ка Татјана (12/25.I) „Ја фрлија пред лавот, но лавот се умилкуваше околу нејзе и не ѝ наштети ништо“; св. Власиј (11/24.II) „Дивите sверови препознавајќи свет човек се приближија околу него, и тој нежно ги милуваше“; св. свешт. мач. Александар (15/28.III) „Потоа го фрлија на sверовите, но sверовите не го ни допреа“; св. Анин Чудотворец (18/31.III) „Со силата на својата молитва $[\ldots]$ sверови скротуваше“; св. мач. Мамант (2/15.IX) „Од неговата светост дивите sверови се припитомувале“; св. мач. Зосим Пустињак (19. IX/2.X) „опкружен со sверови како кротки јагниња“" итн. (Житија светих, 1961, 27, 29, 107, 198, 207, 688, 740).
} 
може да оствари божествена моќ над Божјите креации: „Зашто [...] Севишниот го избра за свое прибежиште; зло нема да ти се случи, [...]; на отровница и на змија ќе нагазуваш, лав и змеј ќе згазуваш“" (Свето писмо, 2017, Пс., 90:9, 10, 13); „од sверовите земни нема да се уплашиш; $[. .$.$] , полските зверови се во мир со тебе“ (Свето писмо,$ 2017, Јов, 5:22, 23) $)^{12}$.

Јудејскиот научник и филозоф Фило Александријски (околу 20 г.п.н.е-50 г.н.е. $)^{13}$ служејќи се со методите на алегориската филозофија ги толкува библиските ликови како аспекти на човечкото суштество, а библиските животни како човечки страсти кои треба да се скротат (Philo, Allegorical 2, 9-11). Во истата насока, и историчарите на уметноста, го толкуваат ликовното претставување на св. вмч. Мина со дивите sверови повикувајќи се на делот од хагиографијата кој се однесува на неговиот живот во пустината ${ }^{14}$. Овде ќе направиме мала дистинкција и ќе наведеме експлицитен пример од хагиографијата на преп. Марија Египетска (1/14.IV) ${ }^{15}$, каде методот на алегориско толкување е потполно применлив во делот на дијалогот помеѓу преподобната и старецот Зосим за нејзината духовна состојба во јорданската пустина. Таа нејзината борба со „безумните страсти“ ја споредува како борба со „лутите зверови“, односно поставува знак за еквивалентност помеѓу двата поими (страсти = sверови): „Првите седумнаесет години ги поминав во оваа пустина борејќи се со моите безумни страсти како со лути sверови““ (Житија светих, 1961, 249) ${ }^{16}$.

${ }^{12}$ Сf. Свето Писмо, 2017, Ис., 11:6-9; Мк., 16:18; Лк., 10:19.

${ }^{13}$ Основен предмет на негова анализа е Мојсиевото петтокнижие при што ја критикува буквалната интерпретација на Библијата.

${ }^{14}$, „[П]овеќе сакал да живее со дивите sверови отколку со луѓето кои не знаат за Бог“.

${ }^{15}$ Во текстот датумите определени за чествување се дадени според двата календари, јулијанскиот и грегоријанскиот.

${ }^{16}$ Но не само тоа, нејзиното посмртно тело е погребано од страна на лав (Voragine, MDCCI, 249). Во Тиквешкиот зборник (1987, 112-130), во текстот „Месец април, во првиот ден: Житие на Марија Египќанка“ пишува: „А Зосима му рече на лавот: «О sверко, повели закопај го ова тело, зашто си голема»“. Овој чин може да се интерпетира како алегорија на нејзиното покајание, или поконкретно кажано, соединувајќи се со Бога при нејзиното вознесение преподобната ги „скротува“ своите „безумни страсти“, односно направените гревови поради кои четириесет и осум години живеела суров, испоснички, пустински живот во покајание. 
Без разлика дали станува збор за алегориски интерпретации или вистински настани ${ }^{17}$, средбите на светителите со дивите животни/ sверовите нашле свое место во фрескоживописот, како на пример претставите на св. Мамант кој јава на лав, св. Игнатиј, кој е претставен помеѓу два лава, св. Христофор Кинокефалос (со песја глава), св. Серафим Саровски со мечката и сл. Сепак, претставата на св. вмч. Мина, кој држи скротени диви зверови, веројатно не е инспирирана само од неговата хагиографија и многубројните препишани текстови, како што претпоставува Поповска-Коробар и не може да се толкува само со библиските извори. За етнологот (фолклористот) не е тешко да даде одговор дека ретките иконографски елементи (дивите sверови) на фреската во Брајчино и иконата во Костур потекнуваат од меѓусебното испреплетување на канонскиот култ кон светителот со обредноста на традиционалниот празничен календар и народните верувања и претстави поврзани со св. вмч. Мина. Со други зборови кажано, ретките иконографски елементи, најверојатно, се создадени врз основа на хагиографските текстови и фолклорниот идентитет на св. вмч. Мина, односно претставените диви sверови се скротени волци.

Св. вмч. Мина во црковниот календар се празнува на датумот на неговата смрт, на 15 хатур (Hathor) во коптската православна црква во Александрија, кој одговара на 24 ноември на грегоријанскиот календар, односно на 11 ноември според јулијанскиот календар. Во македонскиот празничен календар, пред истиот да биде ревидиран од јулијански во григоријански календар во времето кога Македонија била во составот на Кралството на Србите, Хрватите и Словенците, св. вмч. Мина се славел на 11 ноември, а денес на 24 ноември.

Црковниот календар, без разлика на неговото ревидирање, низ текот на столетијата во голема мера бил испреплетуван со народниот празничен календар, чија основна карактеристика, пак, е тесната врска со стопанскиот циклус и неговата обредност при двосезонската делба на годината на летно и зимско полугодие (cf. Стоилов, 1997; 2017; Луческа, 2010а). Месецот ноември, во кој е „попаднат“ датумот на празнувањето на св. вмч. Мина, се смета како граничен период во

17 За ова прашање кај теолошките отци v. Шестоднев Свети Василије Велики (2008), во деветтата беседа која се однесува за животните. 
стопанската година, односно како период на премин од активната кон пасивната, земјоделско-сточарска сезона, кога есента ѝ го отстапува местото на зимата. Оттука и народното верување за св. вмч. Мина како оној кој ја најавува зимата: „Св. Мина му најавил на дедо Зима

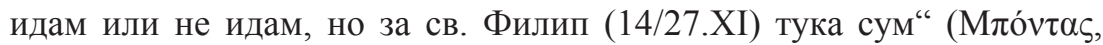
$2013)^{18}$.

Во овој временски период стоката е пуштана слободно да пасе по полето, но истовремено е изложена на опасност од дивите животни, пред се́, од волците кои во потрага по храна одат здружени во глутница и го напаѓаат не само ситниот добиток, туку и сточарите - овчари и козари. Таков е и случајот со селото Брајчино, Преспа, но и со соседните планински села во Костурскиот и Кожанскиот регион каде што култот кон св. вмч. Мина е особено силен и тоа од сосема разбирливи причини. Имено, селото Брајчино, распослано на 1000 м. надморска висина од источната страна на Големото Преспанско Езеро, во една од подлабоките пазуви на планината Баба, зафаќа исклучително ридско-планинско земјиште со 2780,8 хектари пасишта, на кое се́ до годините на Втората светска војна паселе многубројни стада овци и кози (Јовановски, 2005, 57-58). Јужно од селото Брајчино се протега Долна Преспа во јужниот дел од Преспанската Котлина, а на југ од оваа котлина се наоѓа Костурска Котлина со административниот центар градот Костур. Костурската Котлина е опкружена со планините Орлово, Нередска Планина (Вич), Мурик, Грамушта и Горуша, каде геофизичките и климатските услови овозможиле развој единствено на ситниот добиток - овци и кози со специфичен тип на номадско сто-

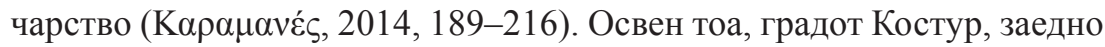
со Кожани, Сјатиста, Серес и Драма, биле значајни преработувачки центри на кожната индустрија уште од византискиот период (XIV век) (Gounaris, 1992, 62-64). Оттука е сосема јасно зошто сточарите во грижата за основното средство на егзистенција - овцата и нејзините производи, барале свој чудотворен помошник во заштитата од дивите sверови, пред се́, од волците кои, во потрага по храна, биле особено присутни на местата со номадски добиток.

${ }^{18}$ Во овој контекст постои и поговорка која се однесува на нешто што треба брзо да се случи: „(Она што) Св. Мина го најави, Филип го дочека“. 
Во македонската народна традиција постојат голем број на верувања и легенди во врска со волците, како и употреба на еуфемизми и разни забрани (табуа) поврзани со неговото име, кои од своја страна, пак, претставуваат извор за стандардизирани обредно-магиски практики во народниот празничен календар. Сите тие имаат една цел - да се онеспособат различните сетила на волците-натрапници со што би се допринело за заштита како на стоката така и на сточарите ${ }^{19}$. Светителите, пак, чии дати за чествување црковните отци ги впишале во месецот ноември, во народната свест станале покровители на стоката и луѓето од различните диви зверови, а меѓу нив, одредени светители, се „специјализирале“ како моќни заштитници од волците. Притоа, неминовно, сточарскиот карактер на своеобразниот календарски момент ја предопределува митологемата за нивно господарство над дивите зверови и волците. Така на пр. св. Димитрија (26.X/8.XI) има функција на заштитник од секаква „дивина“, Архангел Михаил се почитува како „скротувач“ на волкот (8/21.XI), а на само три дена по неговиот празник, на 11/24 ноември, во денот кога се чествува св. вмч. Мина Чудотворец, започнуваат т.н. волчји денови, речиси на целата територија на Македонија ${ }^{20}$. Овие волчји денови се празнуваат еден, три, пет, шест или седум денови, а се познати и под следниве имиња: В `чки празници, В`чјаци, Вучки, В`лкови и Волкови празници, Минуве, Мартинци, Мартинија, Мартиноји празници, Мартинова недела, М'ртенци ${ }^{21}$.

На светогледно и обредно рамниште за време на волчјите празници традицијата бара запазување на редица забрани со апотропејски карактер. Името на волкот во овие денови е строго табуистичко и се заменува со термините: „гад“, „гадурина“, „тој што дави“ (Малинов, 2006, 235), „душман“, „душманин“, „коледарник“ (Тановић, 1927, 16;

19 За волкот како митско и демонско суштество, од една страна, и легендите и обичаите поврзани со него, од друга страна во македонската етнолошка и фолклористичка наука v. Малинов (2007, 191-210), Луческа (2012, 129-137), а во словенската наука воопшто в. Mencej (2001). За светителите заштиници од волците види, исто така, Луческа (2012, 129-137).

${ }^{20}$ Многу поретко волчјите денови започнуваат на празникот на св. апостол Филип $(14 / 27 . \mathrm{XI})$.

21 За именувањето на волчјите празници како Мартинци и претпоставката за смешување на култовите на св. Мартин од Тур со св. вмч. Мина, v. Луческа $(2012,133)$. 
Вражиновски, 1998, 120; Милошеска 2003, 173-175), „дивјак“ (Домазетовски, 1979, 68). Забраните за работа со волна, гребен и ножица се основни и најмногу ги почитуваат жените, кои не треба да предат и сноваат, да ткаат, плетат и мотаат конци, да шијат алишта за мажите, особено ако се овчари ${ }^{22}$. Освен тоа не смеат да допираат предмети како игли, метли, а особено оние предмети кои асоцираат на челуста на волкот - ножици, ковчези и сл. за волчјата уста да остане затворена. И мажите треба да се придржуваат на голем број забрани - не треба да плетат кошеви, да мелат жито, да работат со сврдели, секири, да колат стока, да ораат, па дури не смеат да се бричат и стрижат. Особено се внимава ножевите да се отворат пред почетокот на волчјите денови и да не се затвораат сѐ додека не завршат празниците (Megas, 1963, 21; Китевски, 1979, 56; 1996, 172-173; Вражиновски, 1998, 236, 237, 240, 244, 245; Обрембски, 2001, 138).

Освен забраните, во пресрет на празникот се изведуваат и симболични обредни дејствија во чија основа лежи имитативната магија. Така на пр., во Костурско и Кожанско, жените со конец или со јаже ги заврзуваат ножиците три пати „за да може св. Мина да ја врзе устата

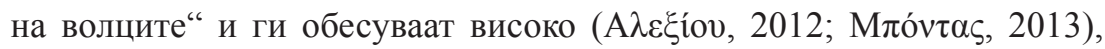
а слично дејствие прават и со веригите од огништето „за да ја затнат устата на волците“. На внатрешната страна на портата заковуваат коњска потковка за да ги „заковаат“ острите заби на волците, или, пак, ги отсекуваат трите краишта на парче платно и со шајки ги забиваат крај огништето „за да ја забијат устата на волците“. Жените, исто така, со затворени очи зашиваат парче од црно волнено платно, при што се применува и дијалошката вербално-обредна формула во која жената што шие вели: „Шијам, шијам!“, другите присутни ја прашуваат: „Што шиеш?“, а таа одговара: „Ја шијам устата на волците, на мечките, на јастребите... (и ги набројува штетниците)!‘‘23

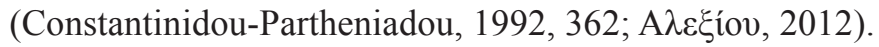

${ }^{22}$ Општораспространет е мотивот во народните приказни за мажот кој бил нападнат од волци, па откако се качил на дрвото морал да го соблече и да им го фрли на волците делот од облеката кој бил сошијан за време на волчјите празници за да се спаси од нивното гонење.

${ }^{23}$ Овој обичај во некои региони се изведува на Летник (1/14.III) (Милошеска, 2003, 173-175). 
Емпирискиот материјал сликовито ја разоткрива народната претстава за св. вмч. Мина како „господар на волците“. Во таа насока, според народното верување, помошта од светителот се бара не само во денот кој е одреден за негово чествување туку и при секоја друга несреќна околност која е поврзана со одгледуваниот добиток: „доколку се помолиш и запалиш свеќа на св. вмч. Мина, тогаш волците нема да го јадат добитокот, а доколку се загуби некое животно, светите-

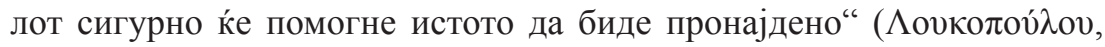


На тој начин светителот не само што се јавува во улога на заштитник од волците, туку се јавува и како чудотворен помошник во пронаоѓањето на изгубените или украдените животни и крадците. Оваа негова способност се должи од една страна на етимологијата на неговото име од глаголот $\mu \varepsilon v \omega ́$ со значење 'информирам', 'откривам', а од друга страна е поврзана со многубројните чуда, запишани од александрискиот архиепископ Тимотеј (380-384), во кои главната фабула се однесува на украдените работи, кои светителот им ги враќа на сопствениците, истовремено казнувајќи ги крадците на кои, пак, им дарува помилување откако ќе се покајат за сторените дела (Sanidopoulos, 2009).

Од изнесената анализа станува јасно дека непознатите зографи од крајот на XV век, кои припаѓале на широкиот уметнички круг со центар во Костур (Вълева, 2007, 263-264; Поповска-Коробар, 2007, 549, 563-565), при исликувањето на ликот на св. вмч. Мина, како на фрескоживописот во Брајчино, така и на костурската икона, направиле „компромис“ помеѓу стандардизираниот иконографски тип на светителот-воин и неговиот фолклорен идентитет како заштитник и господар на дивите зверови - волците. Со други зборови кажано, зад ликовната претстава на светителот се кријат и мноштво на традиционални претстави кои се разоткриваат од народните верувања и од обредите во народниот календар кои, пак, станале неразделен дел од црковното празнување (cf. Стоилов, 2017, 42) ${ }^{24}$. Ваквиот пристап не треба да не́

${ }^{24}$ Љубопитен е фактот, од етнолошка гледна точка, и за идејното вклопување на св. вмч. Мина со св. вмч. Ѓорѓ на фрескоживописот од брајчинската црква. Дали тоа се должи на иконографската програма на сликањето на светите воини во монументалното сликарство или, пак, дополнително и на нивните слични функционални карактеристики во народната свест како заштитници на стоката од дивите sверови? Имено, во очекување 
изненадува, затоа што светите отци уште на Првиот вселенски собор (325) индиректно се изјасниле дека доколку една претхристијанска практика не може да се искорени, тогаш треба да се прифати и преосмисли низ верата во Христа, односно Црквата ја восприема традиционалната обредност која станува дел од христијанските празници со соодветните светителски чествувања (Стоилов, 2017, 34). Друг значаен фактор при формирањето на ваквата светителска претстава се и историските услови од крајот на XV век кога, поради османлиските завојувања, Црквата се стремела да изгради поблизок однос со народот за разлика од претходниот период кога повеќе поддршка барала од владетелскиот круг и благородништвото. Иван Снегаров (1995, 256259) во својата Историја на Охридската архиепископија - патријаршија, во врска со нараснатиот христијански дух помеѓу свештенството и народот во XV и првата половина на XVI век, изнесува податоци за интензивните проповеди на архиепископите Доротеј и Прохор, но и на епархиските архиереи, како костурскиот митрополит Акакиј кој „барал да му помагаат свештениците и верниците во управувањето на епархијата“. Религиозно-моралната состојба кај црковната хиерархија и верниците во овој период се издигнала до тој степен што слободно може да се спореди со ранохристијанскиот период од Римската Империја, особено во поглед на подвижништвото и на мачеништвото за христијанската вера. За тоа говорат не само појавата на новомачениците, туку и записите и натписите во кои се споменуваат дарувањата на црквите и манастирите кои, пак, дејствувале како магнетни пунктови за христијанските верници. Во овој поглед особено се истакнувало монаштвото кое правело напори преку сопствените примери да ја зацврсти христијанската вера и морал меѓу народот (Луческа, 2010а, 38-39). Најверојатно таков е и случајот со монахот Пахомије, за кој

на полното оживување на природата, на границата со најактивната земјоделскосточарска сезона, св. вмч. Ѓорѓи (23.IV/6.V) се почитува за заштитник на овчарите и чувар на овците. Во народниот календар овој ден го обележува почетокот на летото и новата сточарска година. Култот кон светителот, попаднат во таков календарски момент, логично се поврзува со голем број на обредни практики, сврзани со земјоделството и овчарството, кога се најмуваат новите овчари, а стадата се враќаат во бачилата по планините. Оттука при народното восприемање на канонската почит, ликот на св. Ѓорѓ и од војник и змејоборец станува силен заштитник на овчарите и овците од дивите животни, меѓу кои и од волците (Луческа, 2010б, 126-138; 2012, 133). 
Поповска-Коробар $(2007,556)$ претпоставува дека бил еден од ктиторите на Брајчинскиот манастир. Но, таков е и случајот со анонимниот зограф на црквата кој, според авторката, го практикувал стилот на „мајсторите од осумдесетите години“ чии општи карактеристики се „потпирање на ликовната традиција од палеолошкиот период и индивидуалното пренесување на искуството, склоност на нарација и реалистички детали“ (Поповска-Коробар, 2007, 563-565). Всушност, изборот на ктиторите и зографот претставата на св. вмч. Мина со скротените волци да биде исликана на истакнато место на западната фасада од црквата, од десната страна на влезот во храмот, јасно укажува на нивната цел за нејзина силна перцепција од страна на верниците при нивното влегување и изглегување од истиот. Индиректно истите заклучоци се однесуваат и за непознатиот мајстор на костурската икона за кој, како што веќе споменавме, Поповска-Коробар $(2007,557)$ е на мислење дека бил поврзан со „групата на зографи која била ангажирана во брајчинската Св. Петка“.

Стандардизираниот иконографски тип на светител-воин и народниот култ кон св. вмч. Мина како помошник во стопанството, односно господар и скротител на волците продолжил да се негува во Костур и во наредните векови за што говори уште една икона, најверојатно, од крајот на XVIII и почетокот на XIX век, каде светителот е облечен во раскошно декориран панцир, во раката држи копје со знаме и крст, јава на коњ кој чекори во мирен кас и држи јаже на кое се врзани четири волци ${ }^{25}$.

Денес, празникот на св. вмч. Мина особено свечено се празнува во градот Костур со црковна литијна процесија на која се изнесува иконата со ликот на светителот. Овој црковно-народен обичај е поврзан со настанот од 11 ноември 1912 година, кога според народното верување, со помошта на чудотворниот светител, градот Костур успеал да се ослободи од Османлиите без крвопролевање ${ }^{26}$. Како знак на благодарност

${ }^{25}$ Иконата ја пронајдовме на официјалната веб-страна на митрополоијата на Костур и немаме податоци за нејзиното потекло ниту за местото каде моментално се наоѓа. Описот и можното датирање се според А. Василески.

${ }^{26}$ Функционалната карактеристика на светителот како заштитник на војниците произлегува од неговата хагиографија и во таа насока, како во почетоците на неговиот култ, така и во поново време забележани се многубројни настани на неговата 
тие не само што го прогласуваат за патрон на градот, туку и црквата со дедикација на Богородица Музевики (1654) ја посветуваат на св. вмч. Мина, од причина што во внатрешниот нартекс на црквата, на западната страна имало фрескоживописана претстава на светителот:

Претставата со св. Мина на коњ ја среќаваме во долниот појас од западниот sид на Пресвета Богородица Музевики. Околу прикажаната слика бил подигнат понов дрвен иконостас, зашто св. Мина од 1912 година па натаму се смета за патрон на градот Костур, бидејќи денот на ослободувањето на градот се совпаднал со празникот на светите Мина, Виктор и Викентиј (11 ноември). Оттогаш во храмот се празнува патрониот празник во спомен на св. Мина, а не во спомен на Богородица и во негова чест се извршува света архиерејска литургија на 11 ноември. Сликата поради понови зографски интервенции претрпела извесни оштетувања. [...] Фрескоживописот е првата позната претстава на св. Мина коњаник во храмовите

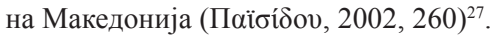

Елементите кои го карактеризираат животот и чудата на светителите, обично се користат од зографите за да ги прикажат веднаш препознатливи од страна на верниците. Таков е и примерот со „брајчинскиот“ и „костурскиот“ лик на св. вмч. Мина каде иконографските претстави се поврзани не само со неговата хагиографија туку и со фолклорниот идентитет на светителот како господар на дивите sверови - волците.

\section{Литература}

Баева, В. (2013). Разкази за чудеса. Локална традиция и личен опит. София: Академично издателство „Проф. Марин Дринов“.

чудотворна помош при воени дејствија: І. Чудотворното спасение на Ираклио, Крит од општ масакар од страна на османлиите на Велигден, 1826 г. кога светителот се појавил во истоимената црква. II. Чудотворната појава во Битката кај Ел Аламејн, која толку го намалила германскиот морал кај војската на генералот Ромел што придонесла за бри-

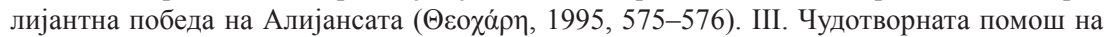
жителите на градот Ќстендил како за време на Руско-турската војна, така и за време на Втората балканска и Втората свестска војна (Попов, 2004, 81).

Потребно е да споменеме дека св. вмч. Мина, освен што се почитува како заштитник од дивите зверови - волците и заштитник на војниците, тој се почитува и како чудотворен исцелител, а особено од најлошите болести како чумата, епилепсијата и сл.

${ }^{27}$ Преводот од грчки на македонски јазик е на колешката проф. д-р. М. Чичева-Алексиќ, за што ѝ се заблагодарувам. 
Василије Велики. (2008). Шестоднев. Прев. С. Јакшић. Нови Сад: Беседа.

Вражиновски, Т. (1998). Народна митологија на Македонците, кн. 2. СкопјеПрилеп: Матица Македонска-Институт за старословенска култура - Прилеп.

Вълева, Ц. (2007). За един иконографски вариант на сцената Оплакване от XV век. Во: Нии и Византија. Зборник радова, т. VI. Ур. М. Ракоција. Ниш: Град Ниш-Универзитет у Нишу-Нишки културни центар, стр. 263-272.

Домазетовски, П. (1979). Есенските обичаи во Дримкол, поврзани со есенските празници и со земјоделската работа. „Македонски фолклор“ бр. 23, стр. 65-72.

Житија светих. (1961). Београд: Свети архиерејски синод Српске православне цркве.

Јовановски, В. (2005). Населбите во Преспа. Местоположба, историски развој и минато. Скопје: Ѓурѓа.

Китевски, М. (1979). Есенски обичаи во Дебарияа (Охридско). „Македонски фолклор“ бр. 23, стр. 53-56.

Китевски, М. (1996). Македонски народни празнищи и обичаи. Скопје: Менора.

Луческа, Е. (2010а). Култот на христијанските светции во Македонија. Историја и традација. Прилеп: Институт за старословенска култура - Прилеп.

Луческа, Е. (2010б). Како се градел култот на свети Ѓорѓ во народната традиција на Македонцичте. „Balcanoslavica“ бр. 37-39, стр. 126-138.

Луческа, Е. (2012). Околу „Волчјите светци“. Во: Tabu w oku szeroko otwartym. Red. N. Długosz, Z. Dimoski. Poznań: Wydawnictwo Rys, str. 129-137.

Луческа, Е. (2018). Култот кон светите мошти во Македонија. Прилеп: Институт за старословенска култура - Прилеп.

Малинов, 3. (2006). Традициискиот народен календар на Шопско-брегалничката етнографска изелина. Скопје: Институт за фолклор „Марко Цепенков““.

Малинов, 3. (2007). Култот на волкот во Кратовско. Празници, верувања, обреди, усно народно творештво. „Музејски гласник“ бр. 4, 191-210.

Марковић, М. (1995). О иконографији светих ратника у источнохришћанској уметности и о представама ових светитеља у Дечанима. Во: Зидно сликарство манастира Дечана. Грађа и студије. Ур. В. Ј. Ђурић. Посебна издања, књ. DCXXXII. Одељење историјских наука, књ. 22. Београд: САНУ, стр. 567-630.

Матичетов, М. (1975). Приказната за наумовата мечка. „Македонски фолклор“ бр. 15-16, стр. 129-145.

Милошеска, Е. (2003). Традищионалната култура во општина Кривогаштани. Кривогаштани: НВО „Хоризонт“.

Моллов, Т. (2000). Миторитуалният произход на някои легенди за св. Наум Охридски (1. Светецът - ездач на мечка). „Електронно списание LiterNet“ бр. 11 (12). https://liternet.bg/publish/tmollov/naum.htm. 9.08.2020.

Моллов, Т. (2001). Народният светеи Гавриил Лесновски - ездач на мечка. „Електронно списание LiterNet“ бр. 5 (18). https://liternet.bg/publish/tmollov/ gavriil.htm. 9.08.2020. 
Обрембски, Ј. (2001). Фолклорни и етнографски материјали од Порече, кн. 1. Ред. Т. Вражиновски. Скопје-Прилеп: Матица Македонска-Институт за стаословенска култура - Прилеп.

Омеслеге, Ф. В. (2008). Acta Sanctorum и болондистичка методологија. Во: Византијски светитељ. Прир. С. Хекел. Београд: Православни богословски факултет, Универзитет у Београду, стр. 210-221.

Попов, Р. (2004). Свети Мина в календарната традищия на балканските народи. „История“ бр. 4-5, стр. 79-88.

Поповска-Коробар, В. (2007). Зидно сликарство с краја XV века у манастирској иркви Свете Петке код Брајчина. „Зборник радова Византолошког Института“ XLIV, стр. 549-565. https://doi.org/10.2298/ZRVI0744549P.

Свето писмо на Стартиот и на Новиот Завет (Библија). (2017). Скопје: Библиско здружение на Република Македонија.

Снегаровъ, И. (1995). История на Охридската архиепископия - патриаршия, т. 2. София: Академично издателство „Проф. Марин Дринов“”

Стоилов, К. (1997). С колесницата на сълнщето из Родопската Света Гора. Асеновградските параклиси - култ и календар. София: СУ „Св. Климент Охридски“, Институт по етнология.

Стоилов, К. (2017). Пространственият календар на Средните Родопи. София: СНЦ „Пьтуващите книги на Стара Загора“.

Тановић, С. (1927). Живот и обичаји народни. „Српски етнографски зборник“ XL.

Тиквешки зборник. (1987). Гл. уред. Б. Павловски, Прев. и предговор Б. Конески. Ком. В. Стојчевска-Антиќ. Скопје: Мисла.

[Baeva, V. (2013). Raskazi za chudesa. Lokalna tradicia i lichen opit. Sofija: Akademichno izdatelstvo „Prof. Marin Drinov“.

Vasilije Veliki. (2008). Šestodnev. Prev. S. Jakšić. Novi Sad: Beseda.

Vrazhinovski, T. (1998). Narodna mitologija na Makedoncite, kn. 2. Skopje-Prilep: Matica Makedonska-Institut za staroslovenska kultura - Prilep.

V'leva, C. (2007). Za edin ikonografski variant na scenata Oplakvane ot XV vek. Vo: Nis i Vizantija. Zbornik radova, t. VI. Ur. M. Rakocija. Niš: Grad Niš-Univerzitet u Nišu-Niški kulturni centar, str. 263-272.

Domazetovski, P. (1979). Esenskite obichai vo Drimkol, povrzani so esenskite praznici i so zemjodelskata rabota. „Makedonski folklor“ br. 23, str. 65-72.

Jovanovski, V. (2005). Naselbite vo Prespa. Mestopolozhba, istoriski razvoj i minato. Skopje: Gjurgja.

Kitevski, M. (1979). Esenski obichai vo Debarca (Ohridsko). „Makedonski folklor“ br. 23, str. 53-56.

Kitevski, M. (1996). Makedonski narodni praznici i obichai. Skopje: Menora.

Lucheska, E. (2010 a). Kultot na hristijanskite svetci vo Makedonija. Istorija i tradici$j a$. Prilep: Institut za staroslovenska kultura - Prilep.

Lucheska, E. (2010б). Kako se gradel kultot na sveti Gjorgji vo narodnata tradicija na Makedoncite. „Balcanoslavica“ br. 37-39, str. 126-138. 
Lucheska, E. (2012). Okolu „,Volchjite svetci“. Vo: Tabu w oku szeroko otwartym. Red. N. Długosz, Z. Dimoski. Poznań: Wydawnictwo Rys, str. 129-137.

Lucheska, E. (2018). Kultot kon svetite moshti vo Makedonija. Prilep: Institut za staroslovenska kultura - Prilep.

Malinov, Z. (2006). Tradiciskiot naroden kalendar vo Shopsko-bregalnichkata etnografska celina. Skopje: Institut za folklor „Marko Cepenkov“.

Malinov, Z. (2007). Kultot na volkot vo Kratovsko. Praznici, veruvanja, obredi, usno narodno tvoreshtvo. „Muzejski glasnik“ br. 4, 191-210.

Marković, M. (1995). O ikonografiji svetih ratnika u istočnohrišćanskoj umetnosti $i$ o predstavama ovih svetitelja u Dečanima. U: Zidno slikarstvo manastira Dečana. Građa i studije. Ur. V. J. Đurić. Posebna izdanja, knj. DCXXXII. Odeljenje istorijskih nauka, knj. 22. Beograd: SANU, str. 567-630.

Matichetov, M. (1975). Prikaznata za naumovata mecka. „Makedonski folklor” br. 15-16, str. 129-145.

Milosheska, E. (2003). Tradicionalnata kultura vo opshtina Krivogashtani. Krivogashtani: NVO: „Horizont“.

Mollov, T. (2000). Mitoritualniat proizhod na nyakoi legendi za sv. Naum Ohridski (1. Svetect-ezdach na mechka). ,Elektronno spisanie LiterNet“ br. 11 (12). https:// liternet.bg/publish/tmollov/naum.htm. 9.08.2020.

Mollov, T. (2001). Narodniat svetec Gavriil Lesnovski - ezdach na mechka, „Elektronno spisanie LiterNet“" br. 5 (18). https://liternet.bg/publish/tmollov/gavriil.htm. 9.08.2020.

Obrembski, J. (2001), Folklorni i etnografski materijali od Poreche, kn. 1. Red. T. Vrazhinovski. Skopje-Prilep: Matica Makedonska-Institut za staroslovenska kultura - Prilep.

Omeslege, F. V. (2008). Acta Sanctorum i bolondistička metodologija. Vo: Vizantijski svetitelj. Prir. S. Hekel. Beograd: Pravoslavni bogoslovski fakultet, Univerzitet u Beogradu, str. 210-221.

Popov, R. (2004). Sveti Mina v kalendarnata tradicia na balkanskite narodi. „Istoria“ br. 4-5, str. 79-88.

Sveto Pismo na Stariot i na Noviot Zavet (Biblija). (2017). Skopje: Biblisko zdruzhenie na Republika Makedonija.

Popovska-Korobar, V. (2007). Zidno slikarstvo s kraja XV veka u manastirskoj crkvi Svete Petke kod Brajčina. „Zbornik radova Vizantološkog Instituta“ XLIV, str. 549-565. https://doi.org/10.2298/ZRVI0744549P.

Snegarov, I. (1995). Istoria na Ohridskata arhiepiskopija - patrijarshija, t. 2. Sofija: Akademichno izdatelstvo „Prof. Marin Drinov“.

Stoilov, K. (1997). S kolesnicata na slnceto iz Rodopskata Sveta Gora. Asenovgradskite paraklisi - kult i kalendar. Sofia: SU „Sv. Kliment Ohridski“, Institut po etnologija.

Stoilov, K. (2017). Prostranstveniat kalendar na Srednite Rodopi. Sofia: SNC „Pytuvashtite knigi na Stara Zagora“.

Tanović, S. (1927). Život i običaji narodni. „Srpski etnografski zbornik“ XL. 
Tikveshki zbornik. (1987). Gl. ured. B. Pavlovski, Prev. i predgovor B. Koneski. Kom. V. Stojchevska-Antikj. Skopje: Misla].

Cabała, B. (1969). Ampułki św. Menasa w zbiorach polskich. „Archeologia” nr. 20, str. 107-118.

Constantinidou-Partheniadou, S. (1992). A travelogue in Greece and a folklore calendar. Trans. M. Papapetrou. Athine: private publication.

Davis, S. J. (1998). Piligrame and the Cult of Saint Thecla in Late Antique Egypt, Vo: Piligrame and Holy Space in Late Antique Egypt. Religions in the Graeco-Roman world, vol. 134. Ed. D. Frankfurter. Leiden: E. J. Brill, str. 303-339. https://doi. org/10.1163/9789004298064_008.

Delehaye, H. (1922). Les martyrs d'Egypte. „Analecta Bollandiana“ vol. 40, str. 5-154, str. 292-364. https://doi.org/10.1484/J.ABOL.4.00624.

Delehaye, H. (1961). The Legends of the Saints. An introduction to hagiography. Trans. V. M. Crawford. Paris: University of the Notre Dame Press.

Dominic, A. (2008). Saints and Animals in the Middle Ages. Woodbridge-Suffolk: The Boydell Press.

Drescher, J. (1946), Apa Mena: A Selection of Coptic Texts Relating to St. Menas. Le Caire: l'Institut français d'archéologie orientale.

Gounaris, K. B. (1992). Economic developments in Macedonia, 1430-1912. Vo: Modern and Contemporary Macedonia. History, economy, society, culture, vol. 1. Ed. I. Koliopoulos, I. Hassiotis-Papazisis. Thessaloniki: Papazisis publishers and $\mathrm{Pa}-$ ratiritis Publishing House.

Grossman, P. (1981). Recenti risultati dagli scavi di Abu Mina. „Corso di Cultura sull'Arte Ravennate e Bizantina" vol. 28, str. 125176.

Gurevič, A. (1987). Problemi narodne kulture u srednjem veku. Prev. L. Subotin. Beograd: Grafos.

Janin, R. (1934). Les églises byzantines des saints militaires (Constantinople et banlieue) (Suite). „Échos d'Orient“ vol. 33, no. 175, str. 331-342. https://doi.org/10. 3406/rebyz.1934.2801.

Janin, R. (1975). La Géographie Ecclésiastique de l'Empire Byzantin, vol. 2: Les églises et les monastères des grands centres Byzantins (Bithynie, Hellespont, Latros, Galèsios, Trébizonde, Athènes, Thessalonique). Paris: Institut Français d'Études Byzantines.

Kaplan, S. (1984). The Monastic Holy Man and the Evangelization of Early Solomonic Ethiopia. Wiesbaden: Franz B. Steiner Verlag.

Kaufmann, C. M. (1910). Zur Ikonographie der Menas-Ampullen: mit besonderer Berücksichtigung der Funde in der Menasstadt nebst einem einführenden Kapitel über die neuentdeckten nubischen und aethiopischen Menastexte. Cairo: Diemer.

Kiss, Z. (2015). Menas i Afrodyta. „Dewocjonalia“ z Sanktuarium Świętego Menasa. „Vox Patrum“t. 35, nr 64, str. 231-248. https://doi.org/10.31743/vp.3714.

Krause, M. (1991). Menas the Miacle Maker Saint. Vo: The Coptic Encyclopedia, knj. 5. Ed. A. S. Atiyah. New York: Macmillan, str. 1589-1590. 
Krumbacher, K. (1907). Miscellen zu Romanos. München: K. B. Akademie der Wissenschaften.

Malek, M. (1981). Saint Mena of Egypt. „Coptic Church Review“ vol. 2, no. 3, str. 99-106.

Mantopoulou-Panagiotopoulou, T. S. (1996). The monastery of Aghios Menas in Tessaloniki. „Dumbarton Oaks Paper“" no. 50, str. 239-262. https://doi.org/10.2307/ 1291746.

Maraval, P. (1985). Lieux saints et pèlerinages d'Orient: Histoire et géographie des origines à la conquête arabe. Paris: Cerf.

Megas, J. A. (1963). Greek Calendar Customs. Athens: Press and Information OfficePrime Minister's Office.

Mencej, M. (2001), Gospodar volkov v slovanski mitologiji. Ljubljana: Oddelek za etnologijo in kulturno antropologijo, Filozofska fakulteta.

Philo of Alexandria. Allegorical Interpretation, II. In: Early Jewish Writings. Ed. P. Kirby. http://www.earlyjewishwritings.com/. 10.08.2020.

Piwowarczyk, P. (2018). Greckie i koptyjskie męczeństwo św. Menasa. Wstęp i przekład z komentarzem. „Śląskie studia historyczno-teologiczne“ t. 51, nr 2, str. 361-375.

Ramsay, W. (1918). The Utilization of Epigraphic Copies. „Journal of Hellenic Studies“" no. 38, str. 124-192. https://doi.org/10.2307/625678.

Redigolo, A. (2011/2012). San Mena: Iconografia, origini e diffusion del culto. [Neobjavena magisterska teza]. Venezia: Universitá Ca 'Foscari.

Sanidopoulos, J. (2009). Saint Menas the Great Martyr and Wonderworker. https:// www.johnsanidopoulos.com/2016/11/saint-menas-great-martyr-resource-page. html. 15.08.2020.

The Great Egyptian and Coptic Martyr, The Miraculous Saint Mena (2005). Pr. and pub. by: Saint Mena Coptic Orthodox Monastery, Maryut, Egypt. Maryut: Saint Mena Monastery Press.

Voragine, A. J. (MDCCI). Legendo Aurea: Vulgo Historia Lombardica Dicta. Edito Secenda. Lipsiae: Impensis Librarie Abnoldiank.

Woodfin, W. T. (2006). An Officer and a Gentleman: Transformations in the Iconography of a Warrior Saint. "Dumbarton Oaks Paper" no. 60, str. 111-143.

Zekry, N. A. (2017). The Iconography of St. Menas in the Coptic Art. ,Journal of the Faculty of Tourism and Hotels-University of Sadat City“" vol. 1, no. 2/2, str. 37-52.

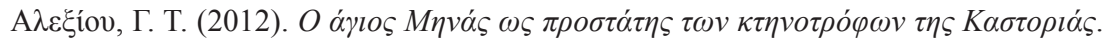
https://fos-kastoria.blogspot.com/2012/12/blog-post.html. 24.07.2020.

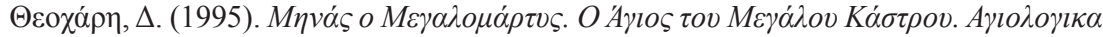

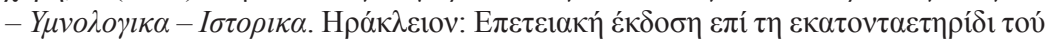

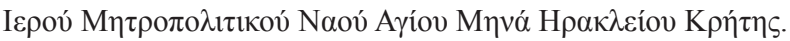

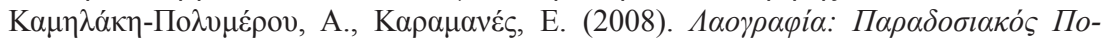

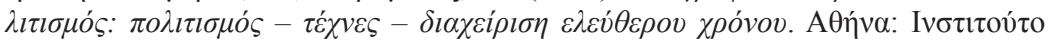

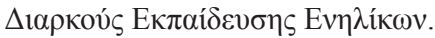




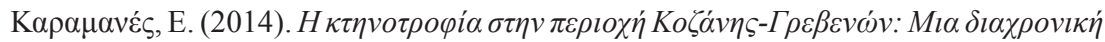

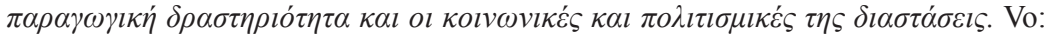

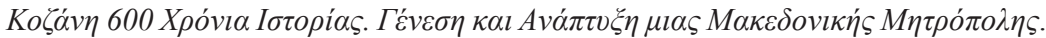

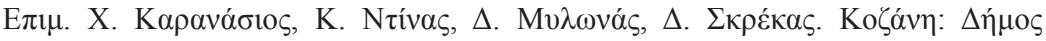

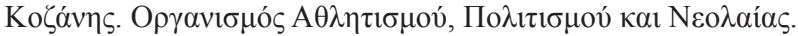


Institut Francais d'Athenes.

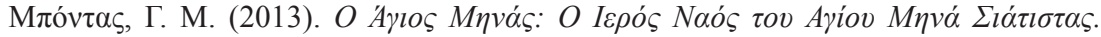
https://e-ptolemeos.gr/. 26.07.2020.

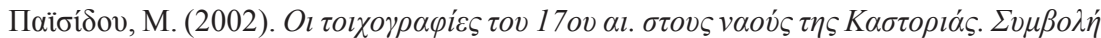

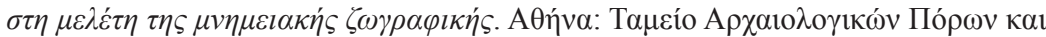

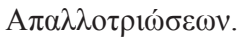

[Alexíou, G. T. (2012). O ágios Minás os prostátis ton ktinotrófon tis Kastoriás. https:// fos-kastoria.blogspot.com/2012/12/blog-post.html. 24.07.2020.

Theochári, D. (1995). Minás o Megalomártys. O Ágios tou Megálou Kástrou. Agiologika - Ymnologika - Istorika. Irákleion: Epeteiakí ékdosi epí ti ekatontaetirídi toú Ieroú Mitropolitikoú Naoú Agíou Miná Irakleíou Krítis.

Kamiláki-Polymérou, A., Karamanés, E. (2008). Laografia: Paradosiakós Politismós: politismós - téchnes - diacheirisi eléftherou chrónou. Athína: Institoúto Diarkoús Ekpaídefsis Enilíkon.

Karamanés, E. (2014). I ktinotrofia stin periochi Kozánis-Grevenón: Mia diachroniki paragogikí drastiriótita kai oi koinonikés kai politismikés tis diastáseis. Vo: Kozáni 600 Chrónia Istorías. Génesi kai Anáptyxi mias Makedonikis Mitrópolis. Epim. X. Karanásios, K. Ntínas, D. Mylonás, D. Skrékas. Kozáni: Dímos Kozánis. Organismós Athlitismoú, Politismoú kai Neolaías.

Loukopoúlou, D., Petropoúlou, D. (1949). I laiki latreía ton Faráson. Athína: Institut Francais d'Athenes.

Mpóntas, G. M. (2013). O Ágios Minás: O Ierós Naós tou Agíou Miná Siátistas. https://e-ptolemeos.gr/. 26.07.2020.

Paisídou, M. (2002). Oi toichografies tou 17 ou ai. stous naoús tis Kastoriás. Symboli sti meléti tis mnimeiakís zografikis. Athína: Tameío Archaiologikón Póron kai Apallotrióseon]. 